\title{
Comparative Study of Nursing Ph.D. Education System and Curriculum in Iran and Alberta School of Nursing
}

\author{
Adib Hajbaghery. $\mathrm{M}^{1 *}$ \\ Nabizadeh Gharghozar. Z \\ Bolandianbafghi. Sh ${ }^{2}$ \\ 1- ( ${ }^{*}$ Corresponding Author) \\ Ph.D. In Nursing , Professor, \\ Trauma Nursing Research \\ Center, Faculty of Nursing, \\ Kashan University of Medical \\ Sciences, Kashan, Iran. \\ Email: adib1344@yahoo.com \\ 2- Ph.D. Candidate. Trauma \\ Nursing Research Center, \\ Faculty of Nursing, Kashan \\ University of Medical Sciences, \\ Kashan, Iran.
}

\begin{abstract}
Introduction: In order to adapt a fast changing health care system, it is necessary to prepare the content of a high-quality nursing program. Comparing different educational systems is one of the evaluation methods that improves the content and quality of the curriculum.
\end{abstract}

Objective: The aim of this study was to compare comparative nursing education in Iran and Alberta and provide practical suggestions for improving its quality.

Materials and Methods: This descriptive-comparative study was performed in 2018. The four-stage Beredy model of description, interpretation, neighborhood and comparison was used to compare the Iranian nursing education system to the Nursing Faculty of Alberta university. Data were collected by Persian and English Googling. Then, the data were compared according to the aim of the research.

Results: The program of both universities based on the principles of strategic planning with mission, vision and values. At Alberta University, the attention was focused onappropriate link between the lesson plan and the needs and problems of the community. The Ph.D. curriculum of the Iranian Nursing have a lot in common with that of University of Alberta regarding profile and structure of the course. Also, the comparison showed that applying the University of Alberta is subjected to having a postgraduate degree in nursing and a certificate in research statistics and language proficiency and clinical recordsare essensial for non-Canadians. But in Iran, student admission is subject to a master's degree.

Discussion and Conclusion: One of the strengths of the Ph.D. program in Iran can be the alignment of the values and beliefs of the program based on the Islamic values system and gaining competencies such as critical thinking, clinical argumentation, problem solving, evidence-based decision making, and the recording of an analytical report. Lacking the clinical base and the absolute emphasis on theory and especially research are the weaknesses. Therefore, based on the experiences of the advanced countries and the needs of the Iranian community, we need to correct the weaknesses and strengthen the strengths.

Keywords: Bereday's Model, Canada (Alberta), Comparative Study, Curriculum, Iran, Nursing. 


\section{مقايسه تطبيقى نظام آموزشى دوره دكتراى تخصصى برستارى در ايران و دانشكده بر ستارى آلبرتا}

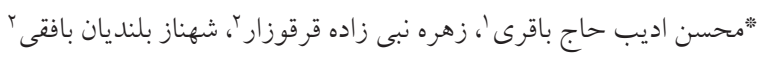

جكيده

مقدمه: براى انطباق با سيستم مر اقبت بهداشتى كه به سرعت در حال تغيير است، نياز به آماده كردن برنامه درسى يرستارى با كيفيت بالا است. مقايسه نظامهاى مختلف آموزشى، يكى از روشهاى ارزيابى است كه باعث ارتقاى محتوى و كيفيت باتي برنامه آموزشى مىشود.

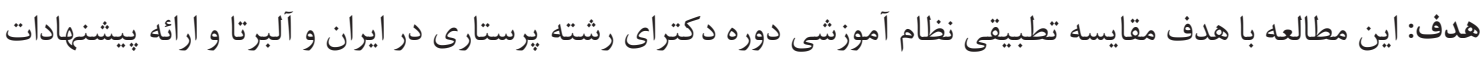
عملى جهت بهبود كيفيت آن انجام شده است.

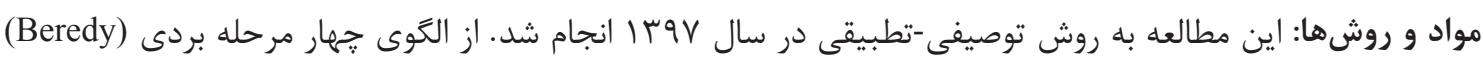

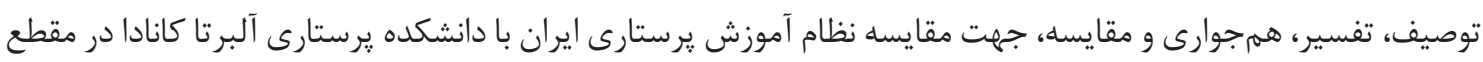

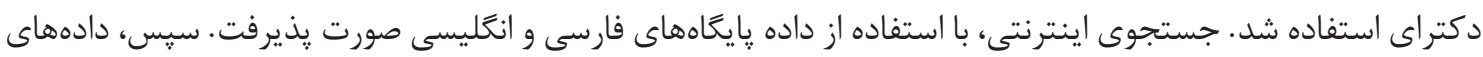

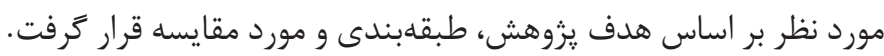

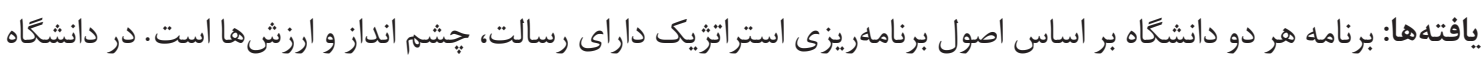

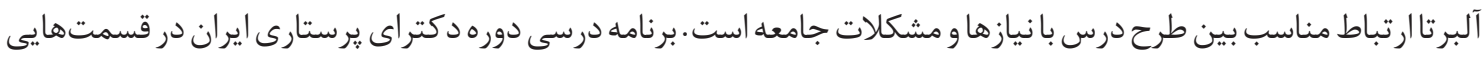
مانند مشخصات و ساختار دوره نقاط مشتركى با برنامه درسى دوره دكتراى يرستارى دانشاه آلبرتا دارد. همجنين مقايسه

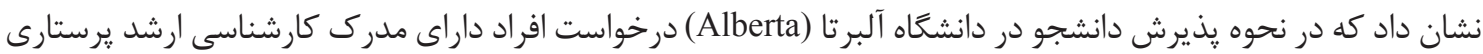

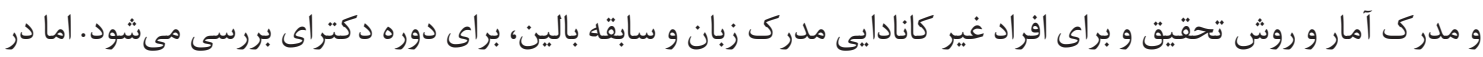

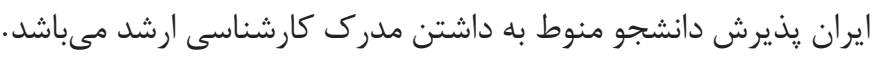
بحث و نتيجه كيرى: از نقاط قوت برنامه دكتراى در ايران مىتوان به منطبق بودن ارزشها و باورهاى برنامه بر اساس نظام ارزشهاى اسلامى و كسب شايستگى هايى مانند تفكر نقادانه، استدلال بالينى، حل مسئله، تصميمَيرى مبتنى بر شواهد و

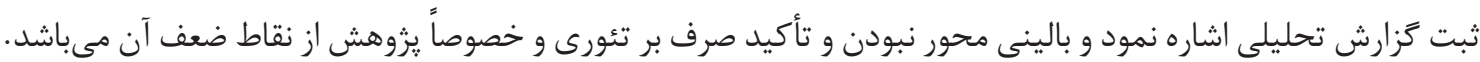

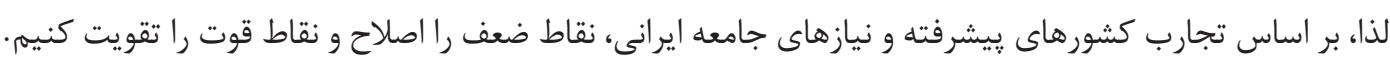

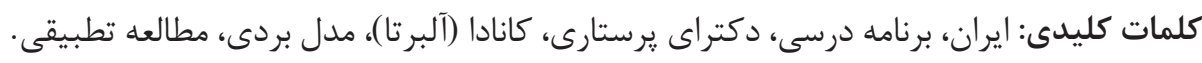

\begin{tabular}{|c|c|c|}
\hline $1 \mu q V / 1 \mu / \kappa^{6}$ & تاريخ دريافت: ت & 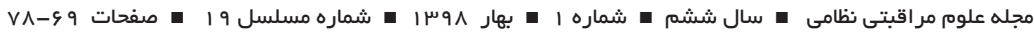 \\
\hline І & 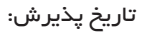 & \\
\hline १ & 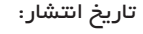 & \\
\hline
\end{tabular}

كه به سرعت در حال تغيير است نياز به آماده كردن برنامه درسى

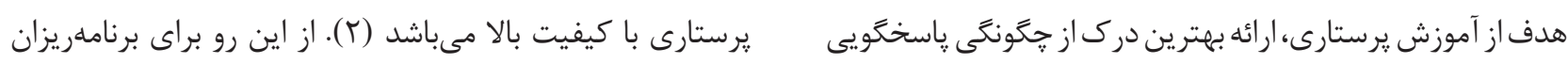

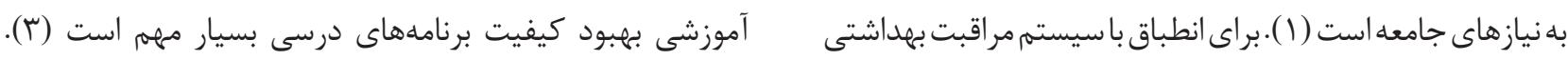


در شهر ادمونتون (Edmonton) ايالت آلبرتا در كانادا تأسيس شده

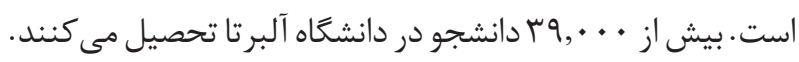

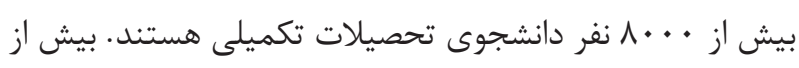
VV. .

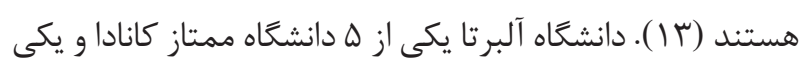

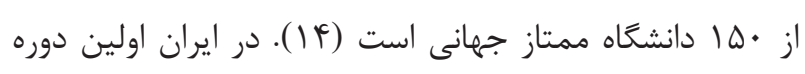

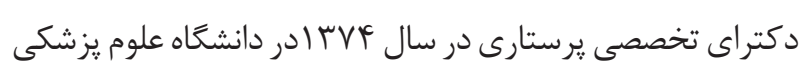
تبريز آغاز شد و امروزه شاهد راه اندازى اين مقطع تحصيلى در داري 19 دانشخاه علوم يزشكى كشور هستيم كه تعداد يذيرش آن آن سالانه

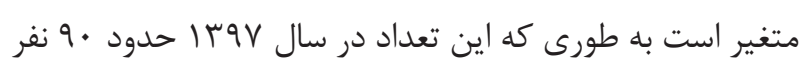

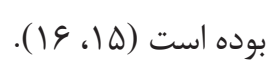

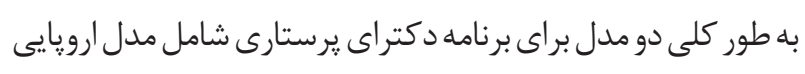

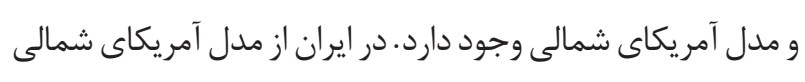

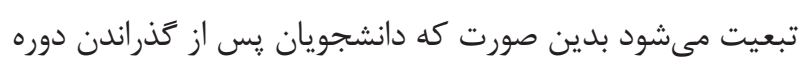

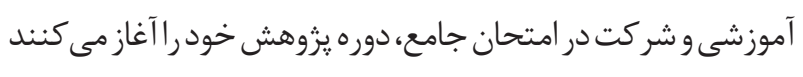

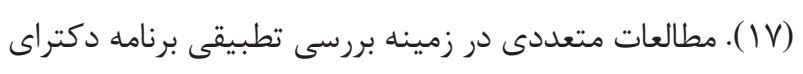

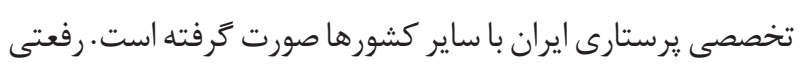

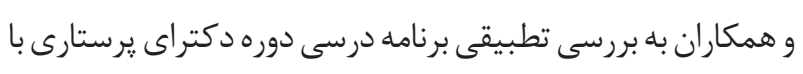

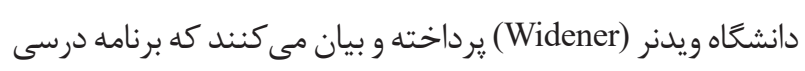
دوره دكتراى يرستارى ايران فقط در قسمتهايى مانند مشخصات

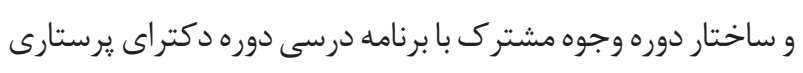

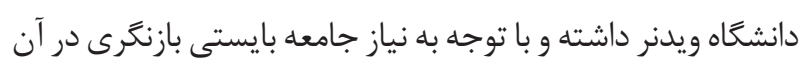

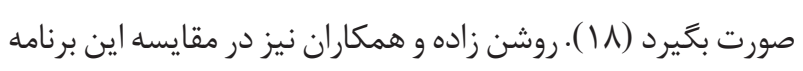

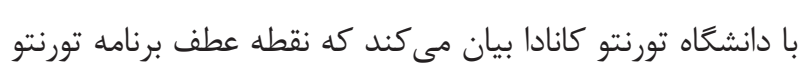
به روزرسانى مدون آن است. در ايران با توجه به نيازهاى در حال

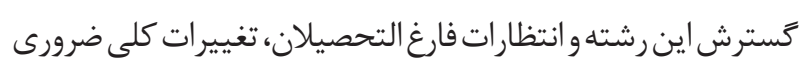
است (19) ). به طور كل مطالعات بيان شده از جنبههاى مختلفى

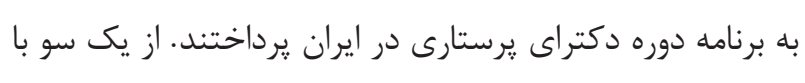
توجه به حساس و مهمم بودن نقش برنامههاى درسى در ايفاى بهتر

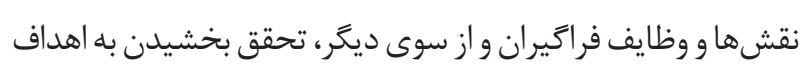

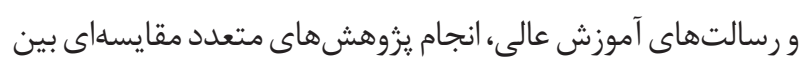

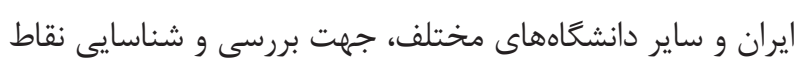
ضعف و قوت برنامه درسى ايران ضرورى بوده و بايستى ضمن تحليل

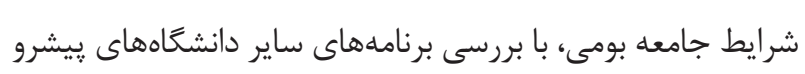

برنامههاى باكيفيت بالا، دانشجويان باكفايتى را براى آينده تربيت

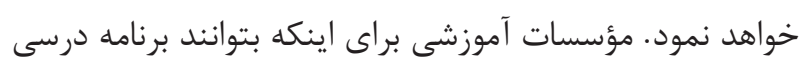

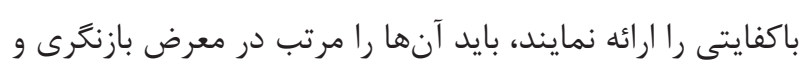

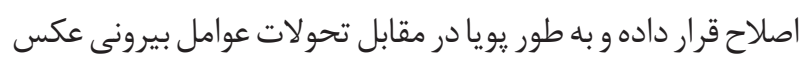
العمل مناسب نشان دهند تا بتوانند نقش مهم خود را به عنوان ابزار

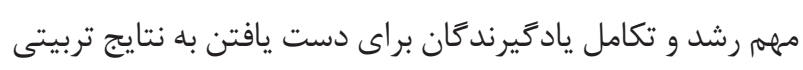

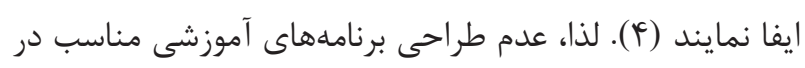
رشته يرستارى، خسارات جبران نايذيرى بر سلامت جامعه و اعتبار علمى دانشَاه وارد مى كند (ه). دوره دكتراى تخصصى، بالاترين مرحله دانش يزوهى و يِيشرفت داه

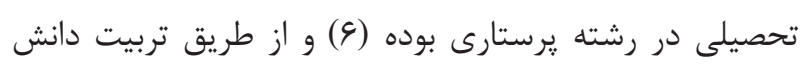

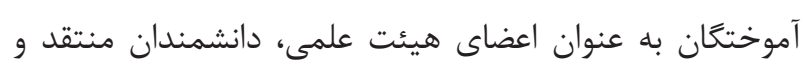

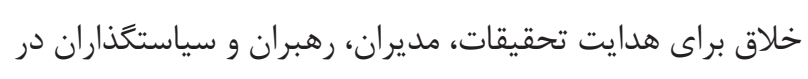

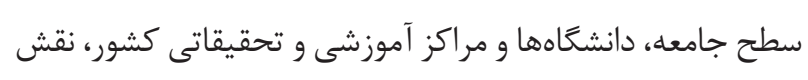
مهمى در ييشرفت و توسعه رشته يرستارى ايفاى مىنمايد (V، N).

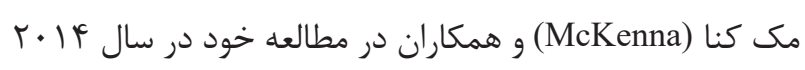

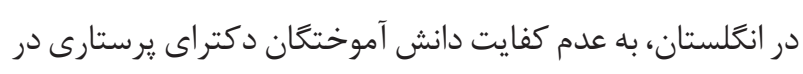
رويارويى با خالش هاى موجود در نظام مراقبت سلامت اشاره نموده و بيان داشتهاند انتظار مىرود فارغ التحصيلان اين مقطع، افراد حرفهاى و با بصيرتى بوده و با برخوردارى از بينش عميق بر مسائل

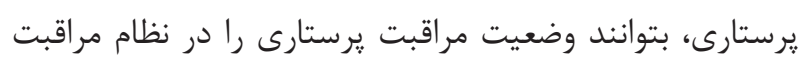

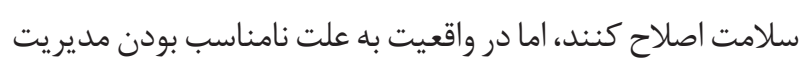

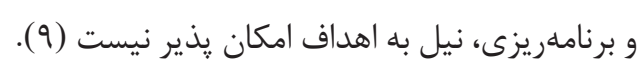

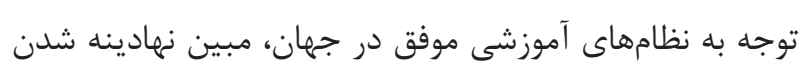

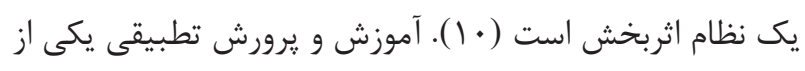

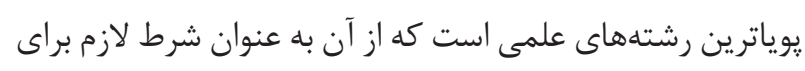

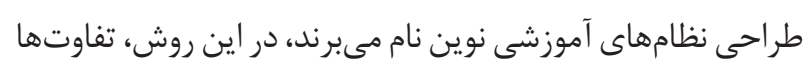
و شباهتهاى نظامهاى گوناگون آموزشى بررسى شده، دلايل

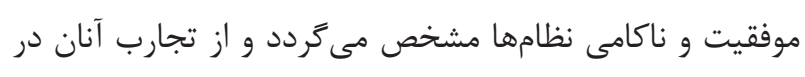

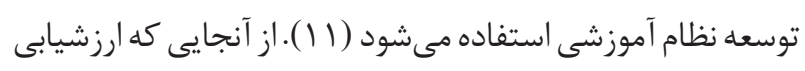

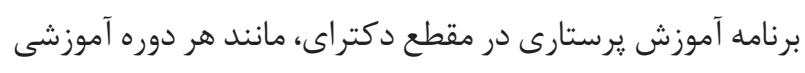

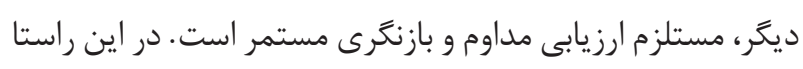

استفاده از روش يزوهش تطبيقى، كمك كننده است (r I I).

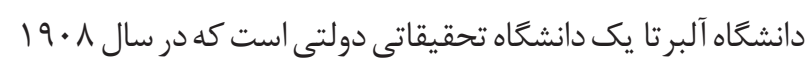


است، بنابر اين شناخت بافت مورد مطالعه از اهميت زيادى برخوردار

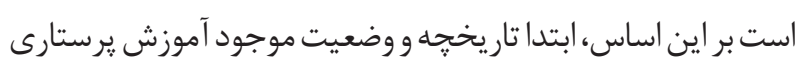
در دكتراى در ايران بررسى شد. در ادامه، همين وضعيت در دانشعاه

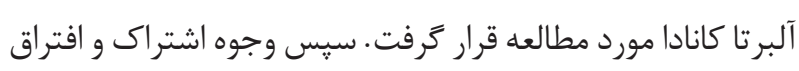

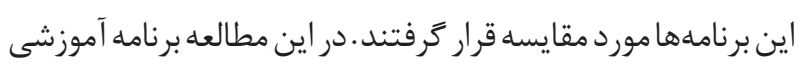

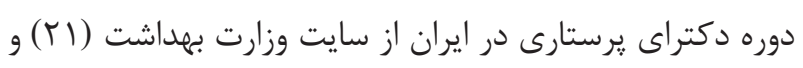

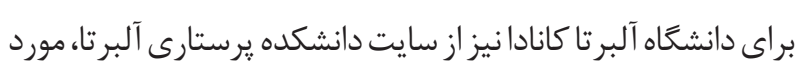

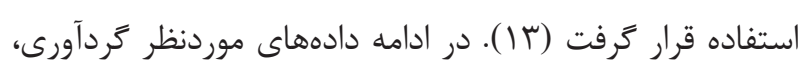

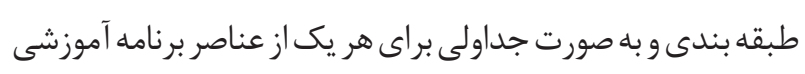
ارائه و مورد مقايسه قرار كرفتند.

يافتهها نتايج حاصل از مطالعه و مقايسه در مورد هر يك از عناصر برنامه

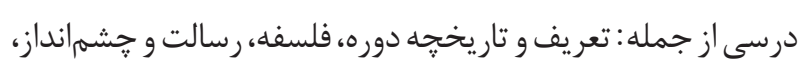

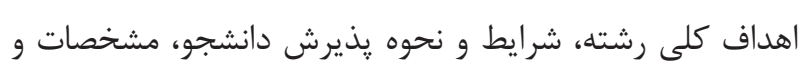
ساختار دوره به تفكيك در جداول يك تا جهار ارائه شده است. همان طور كه جدول شماره ا نشان مى دهد دكتراى يرستارى آلبرتا

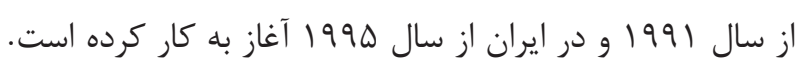

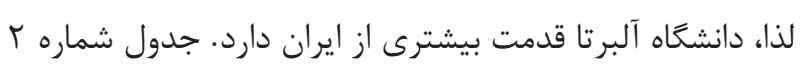

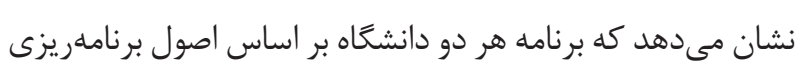

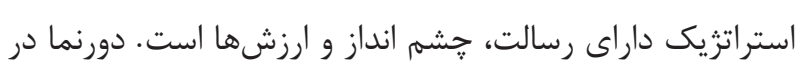

در اين زمينه به تحليل شرايط موجود يرداخته و در جهت ارتقاى برنامه اقدام شود. با توجه به اينكه دانشعاه آلبرتا يكى از ه د دانشخاه

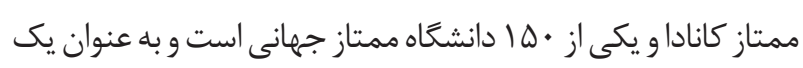

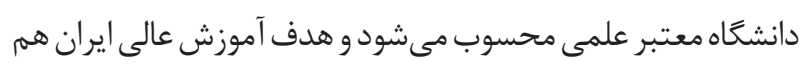

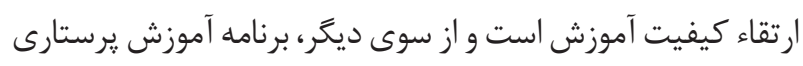

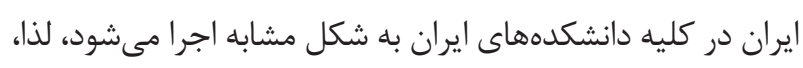

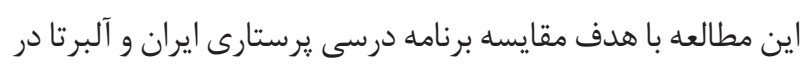

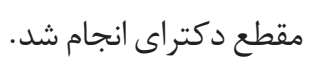

مواد و روشها يزوهش حاضر يك يزوهش كاربردى به شيوه توصيفى تطبيقى است

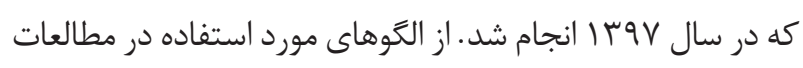
تطبيقى، الكوى بردى است. اين روش از جهار مر حله توصيف، تفسير،

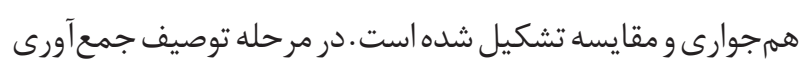
اطلاعات انجام مى شودو در مر حله تفسير، اطلاعات جمع آورى شده

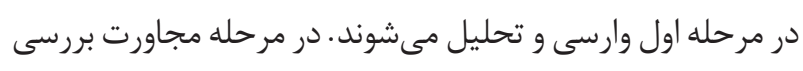

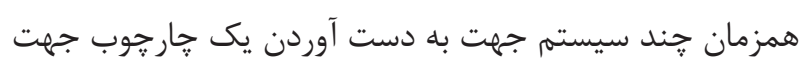

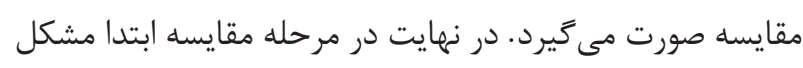

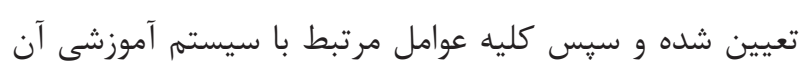

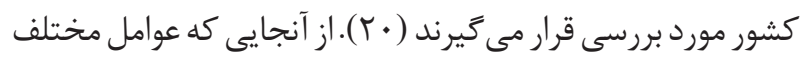
فرهنكى و اجتماعى بر يايهر يزى سيستمهاى آموزشى متفاوت، مؤثر

جدول ا - تعريف دوره و تاريخجه

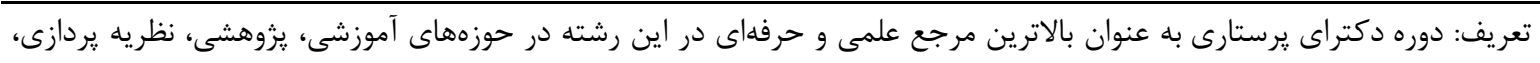

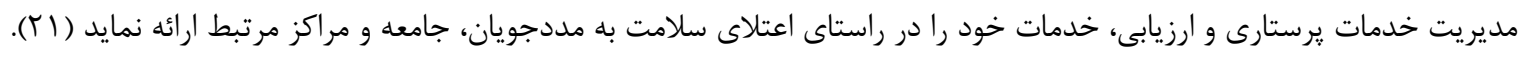

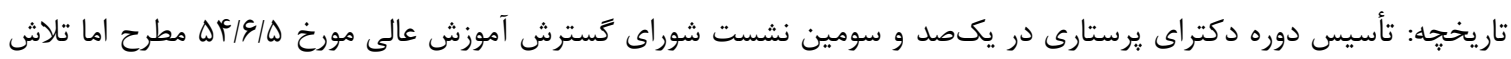
ايران

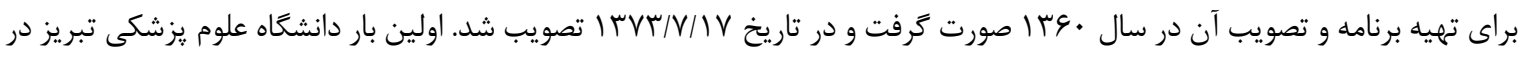

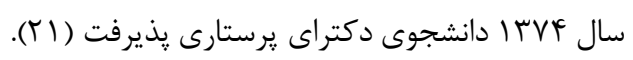

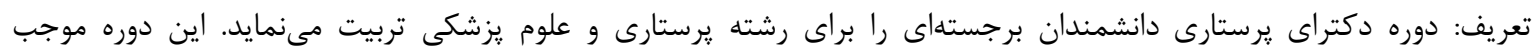

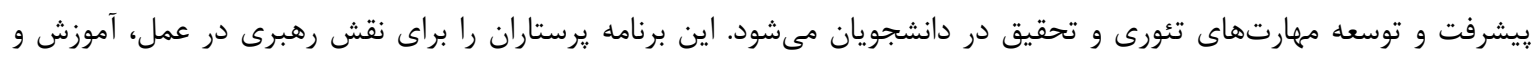

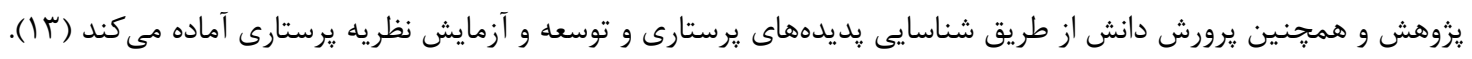

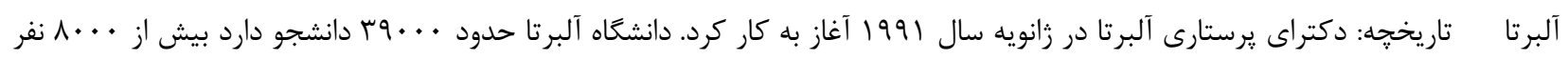

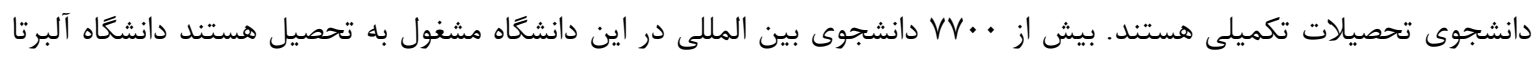

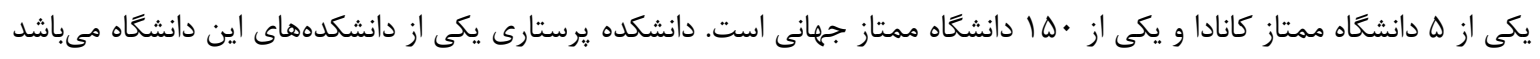


جدول r- فلسفه، رسالت، جشم اندازها و اهداف كلى

\section{فلسفه، رسالت و جشم اندازها}

فلسفه: يرستارى از سويى با سلامت انسان به عنوان موجودى منحصر به فرد و جند بعدى و از سويى ديخر بر اساس نظام ارزشهاى

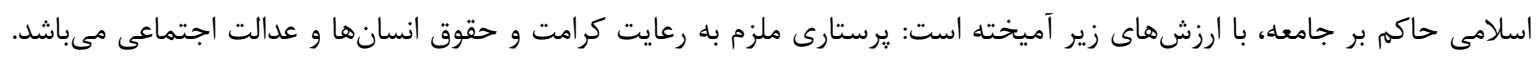

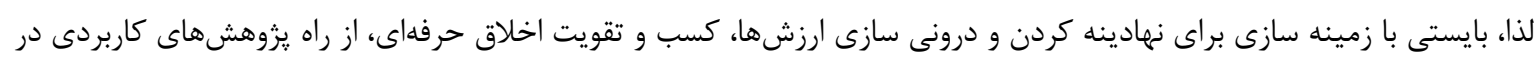

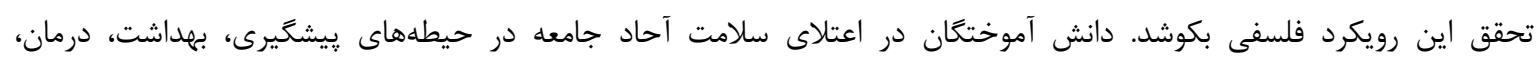

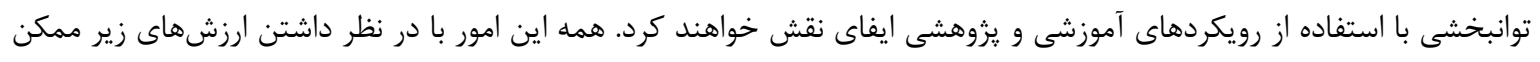

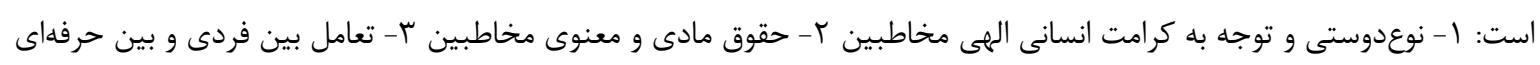

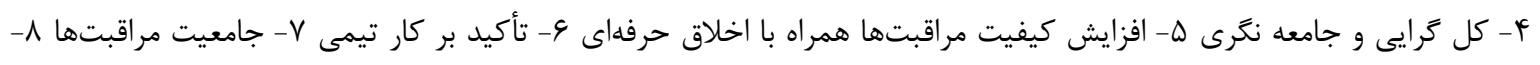
مددجو محورى

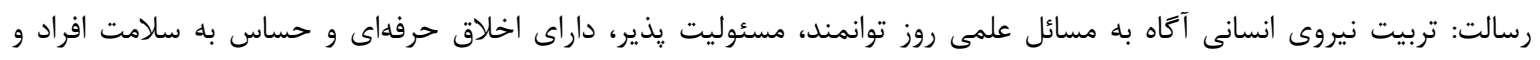

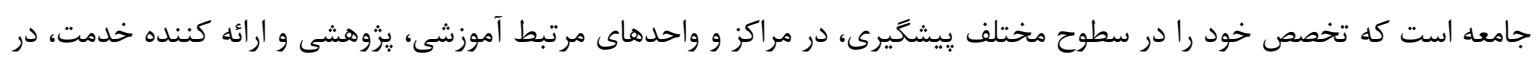

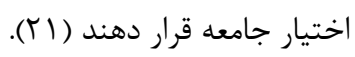

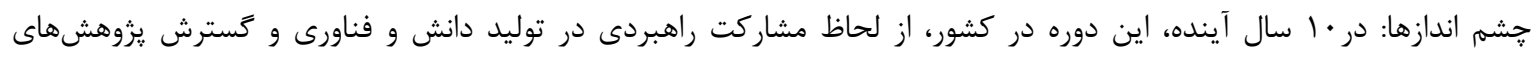

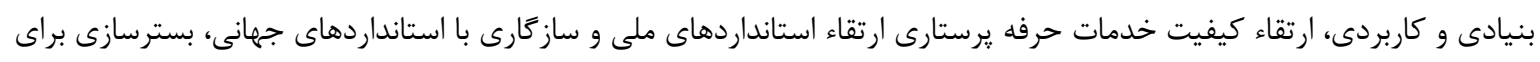
جذب نيروهاى كارآمد علمى و تخصصى در داخل كشور و جذب دانشجوى خارجى دي در رديف كشورهاى برتر و مطرح در منطقه خواهد

بود (Y) (r)

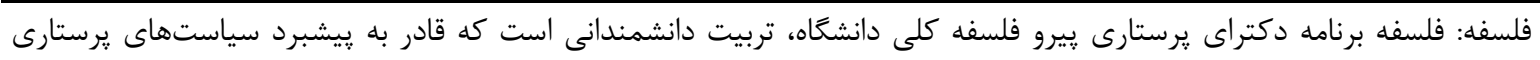

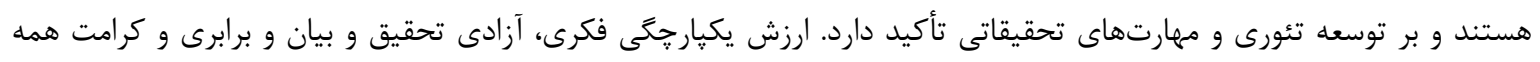

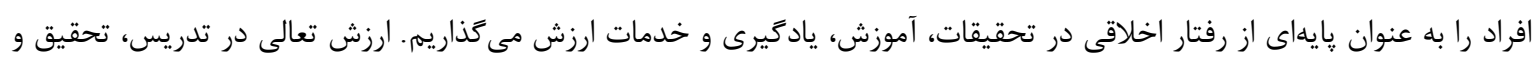

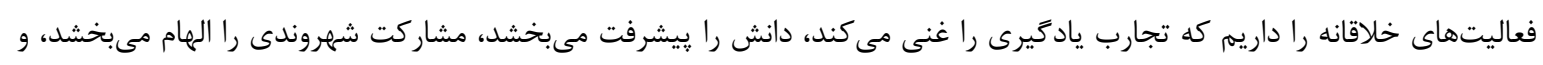

خير عمومى را مى خواهد (ساليت (1).

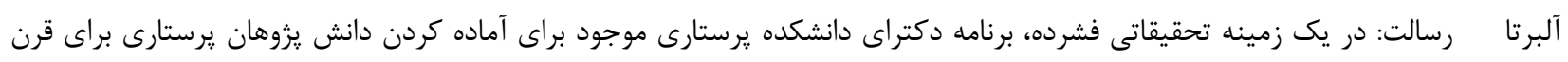

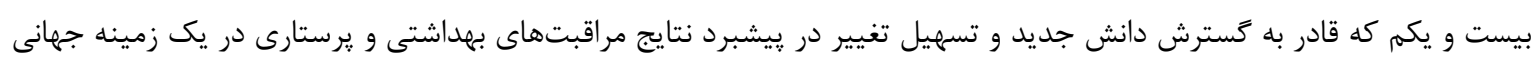

باشند (1) ب (1). جشم اندازها: دانشجويان در برنامه دكترا مشغول به تحصيل هستند و براى برترى در توسعه، سازماندهى و ارزيابى دانش جديد

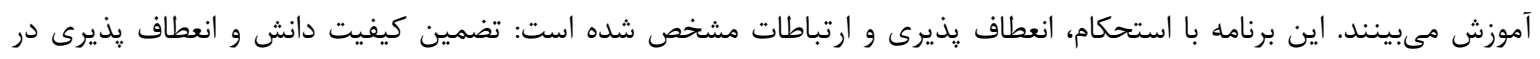
ارتباط با رشته يرستارى و اهداف شغلى دانشجويان و منافع تحقيقاتى (ب ا ).

الئَاه

رضايت خدمت كيرندكان و خدمت دهندكان مىباشد (Tr). ر دانشگاه آلبرتا، به ارزش يكيار جكى فكرى، آزادى تحقيق و برابرى

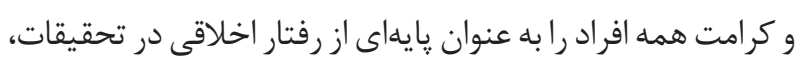
آموزش، ياد گيرى و خدمات تأكيد شده است. بر طبق جدول شماره س، نحوه يذيرش دانشجو در دانشعاه آلبرتا با

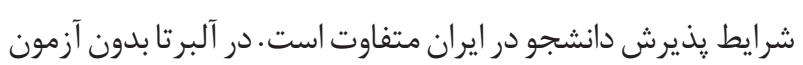

هر دو دانشعاه خلاصه، قابل درك و روشن عنوان شده و دقيقاً در راستاى رسالت عنوان شده و يك وضعيت ايده آل را تبيين مى كند. ارزشها و باورهاى برنامه در ايران بر اساس نظام ارزشهاى اسلامى رسى حاكم بر جامعه ابراز شده تأكيد آن بر توسعه فرهنگ تقوا و تكامل انسانى، حفظ كرامت انسانى، استقرار عدالت اجتماعى، رعايت اخلاق يزشكى، تلاش براى استقرار نظام شايسته سالارى، تأمين 
دانش (Synthesizing Knowledge) است كه تمركز بر مراحل انجام انواع بررسىهاى متداول سيستماتيك دارد كه اين واحد

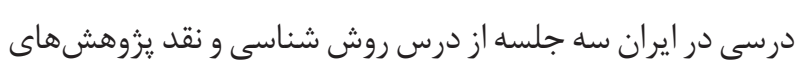
كمى و كيفى محسوب مىشود كه به صورت فشرده ارائه مى كر ددد. نام واحد ديخرى كه در اين دوره دانشجويان مى كذر مانند استفاده

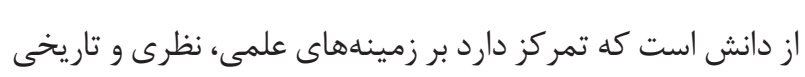

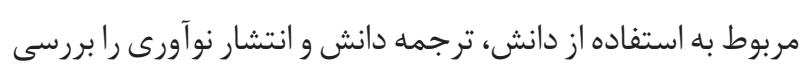

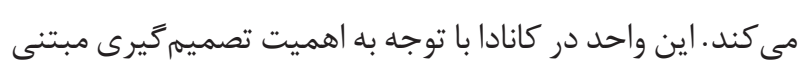

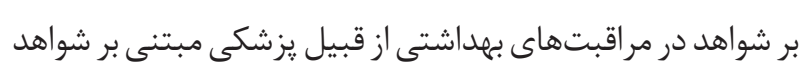

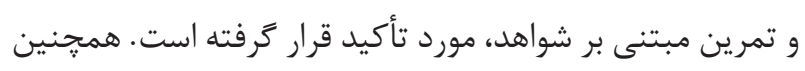
توجه خاص به جالشهاى استفاده از دانش در سازمان هاى يِيجيده

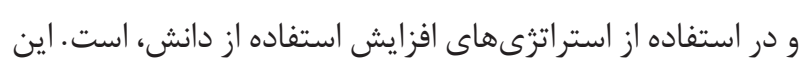

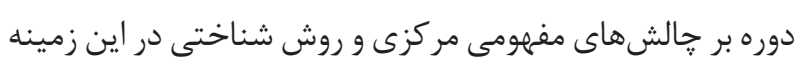

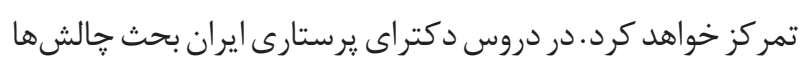

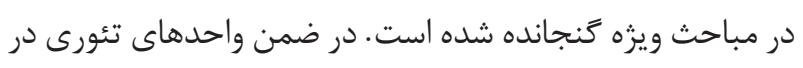

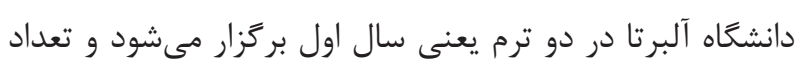

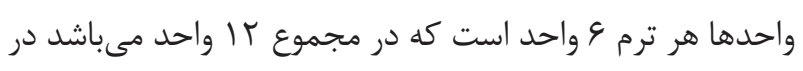
صورتى كه در ايران دروس تئورى در طى سه ترم و ودر در مجموع دمرع
است ونياز بها رائه مداركى از جمله كارشناسى ارشد يرستارى بامعدل

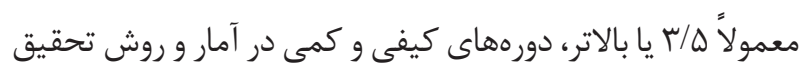

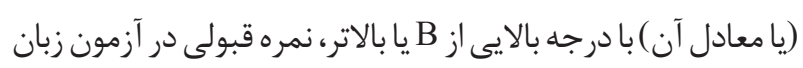
انغليسى تافل (TOEFL) براى افراد غير كانادايى و انجام مصاحبه با باديا

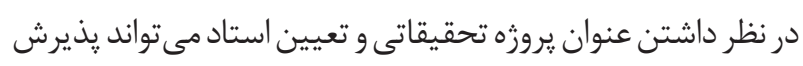

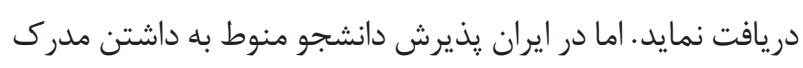

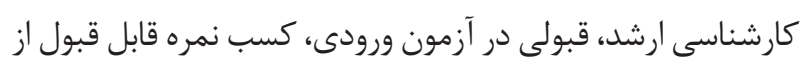

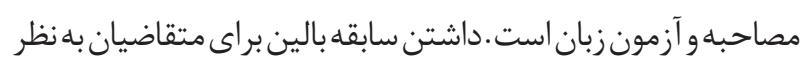

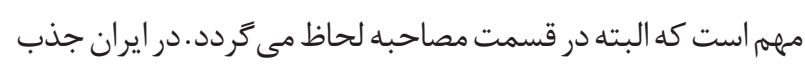

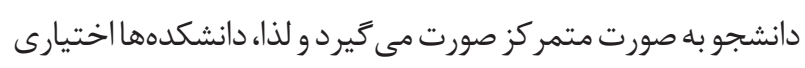

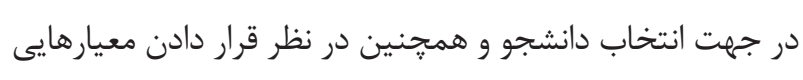

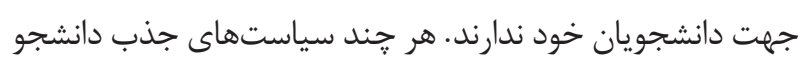
در ايران به طور متمركز است ولى در صورت توجه به عدان عدم تمركز دانشكدهها حداقل در جذب دانشجو، آنها مى توانند دانشجويانى را كه با معيارهايشان تطابق بيشترى دارند جذب نمايند. بر طبق جدول شماره \& از نظر مشخصات و ساختار دوره تعداد

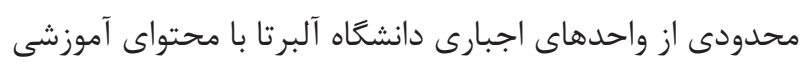

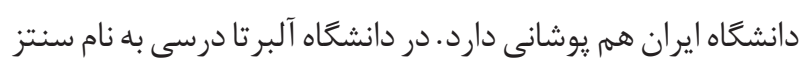

جدول r- شرايط و نحوه پِيرش دانشجو

شرايط ورود به دوره دكتراى تخصصى مصوب شوراى عالى برنامهريزى شامل: داشتن شرايط عمومى ورود به آموزش عالى، داشتن

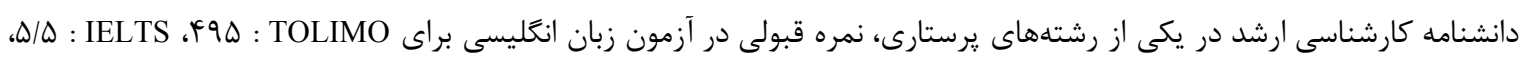
ايران ش ش

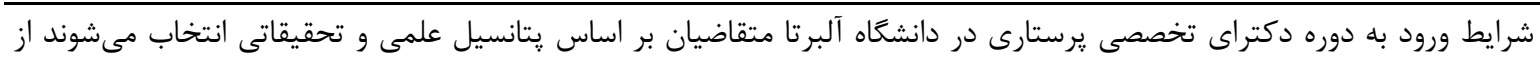

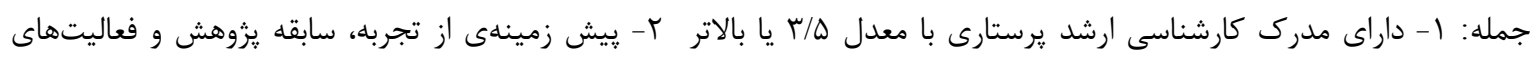

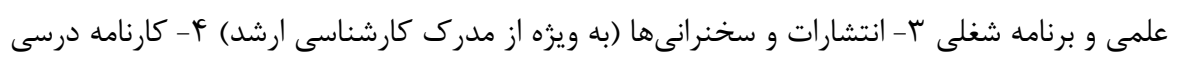
حداقل الزامات عبارتند ازئ

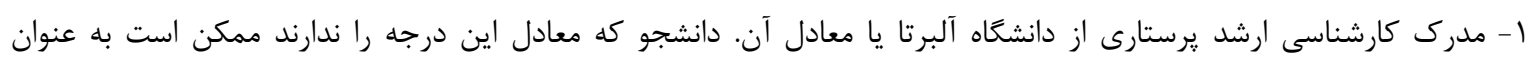

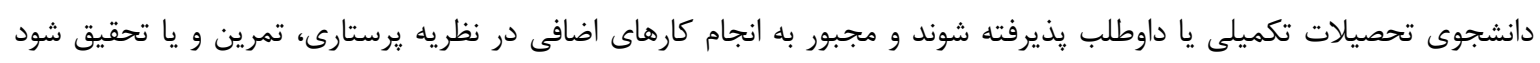

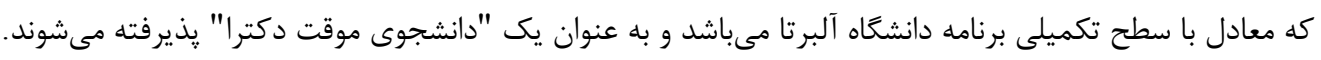

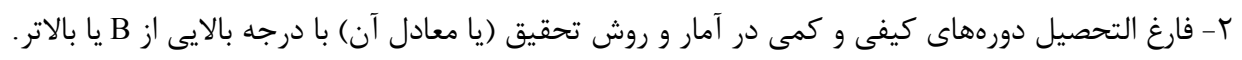
r- تكميل مصاحبه با استاد راهنما

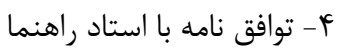

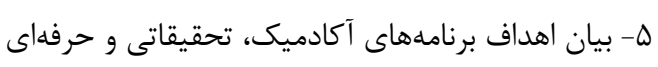

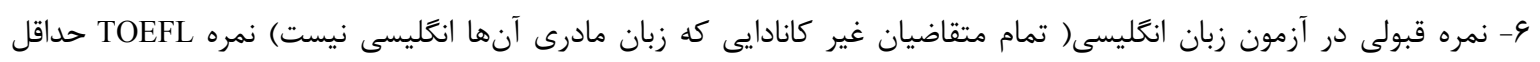

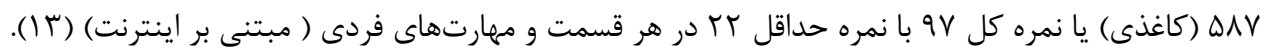




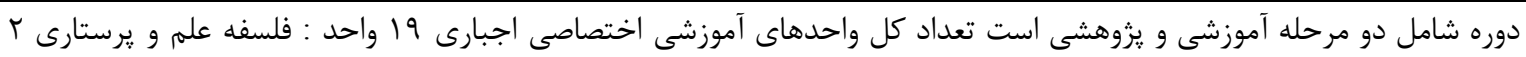

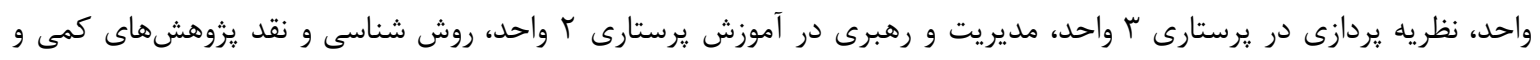

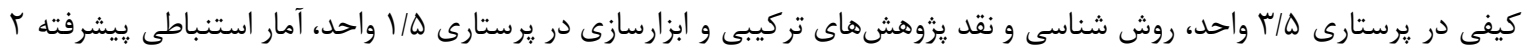

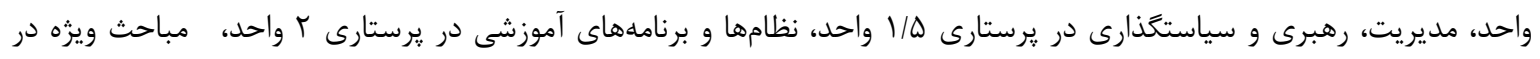

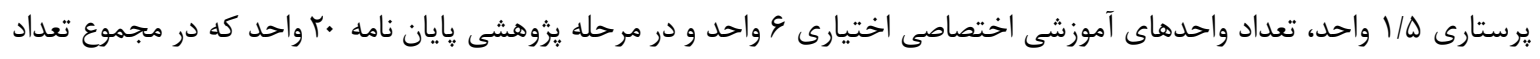

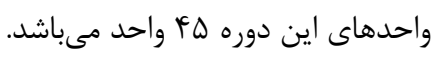

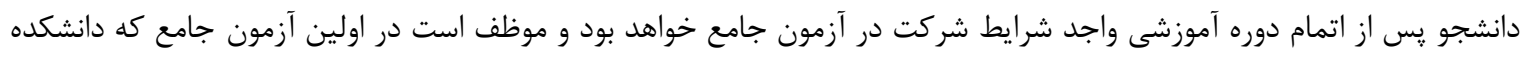

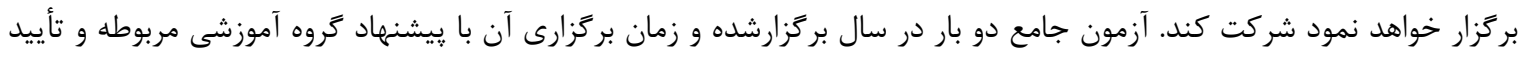
شوراى تحصيلات تكميلى دانشكده مى مباشد.

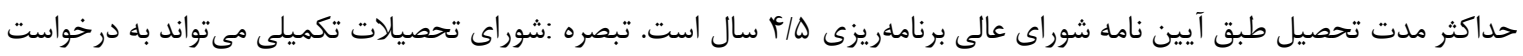

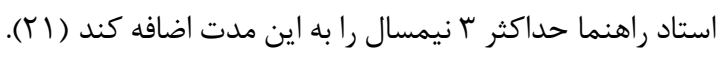

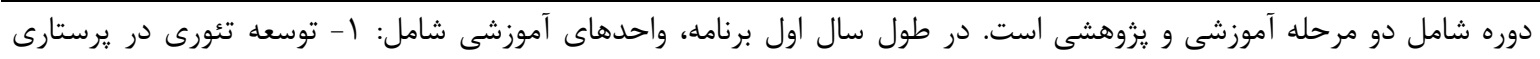

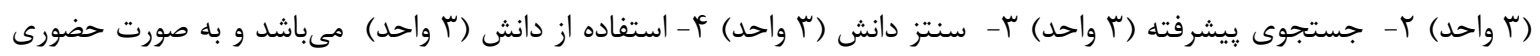
ارائه مى در طول سال دوم برنامه، در طى دو ترم، سمينار يايان نامه( ب واحد) بركزار مىشود كه يِيش نياز آن كذراندن واحدهاى سال اول

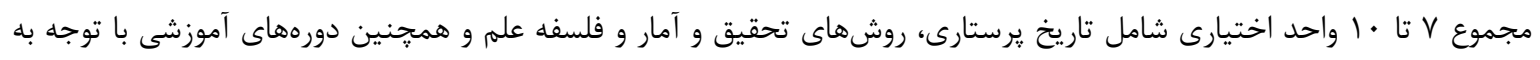

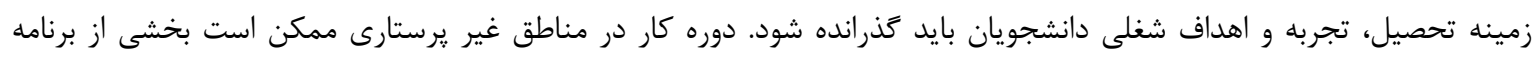

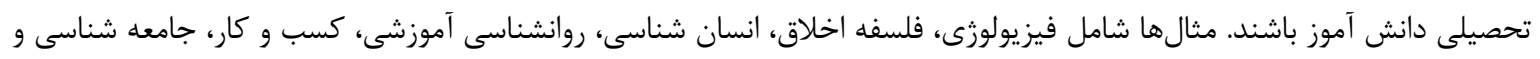

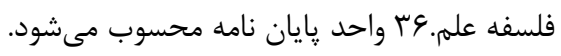

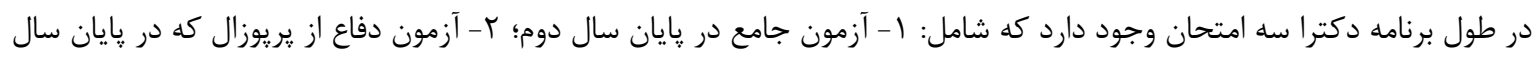

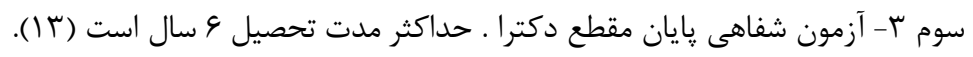

دكتراى يرستارى ايران، در هر ترم دانشجو اين مقطع بايد ب واحد

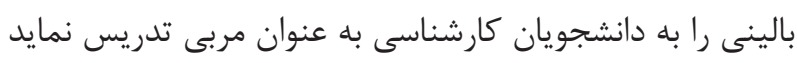

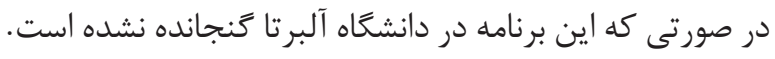

\section{بحث و نتيجه}

هدف كلى مطالعه حاضر مقايسه تطبيقى برنامه درسى دوره ند دكتراى

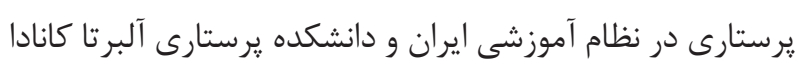
بوده است. با توجه به نتايج بيان شده در اين مقاله موارد زير قابل وديل بحث و ي بيشنهاد است. رسالت دانشعاه آلبرتا از دوره دكتراى يرستارى آماده كردن دانش

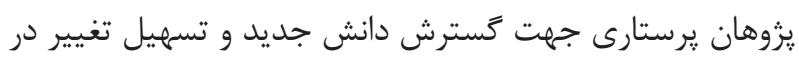

19 واحد بركزار مىشود. در آلبرتا سال دوم مبحث سمينار در هر

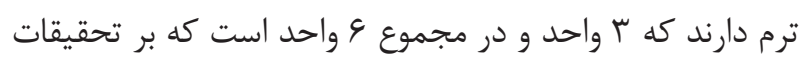

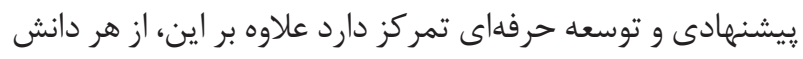

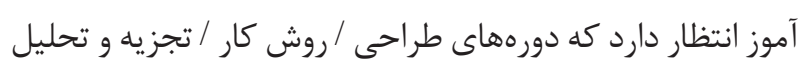

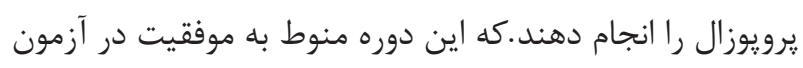

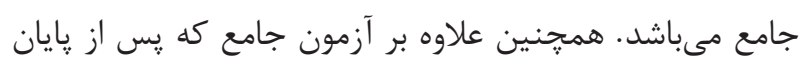

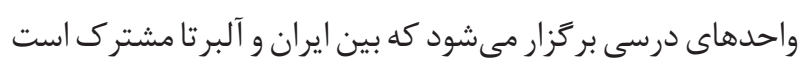

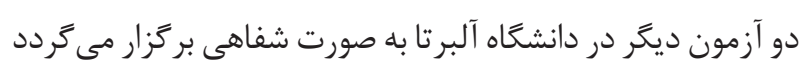

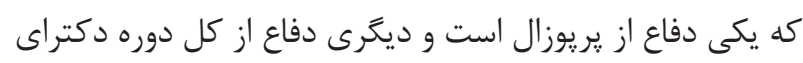

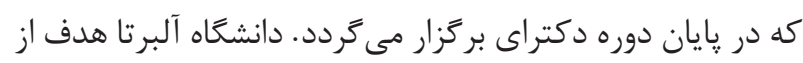

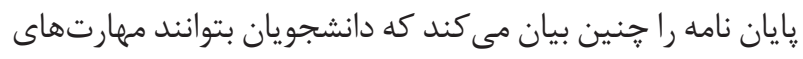

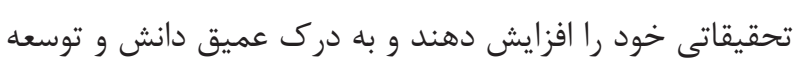

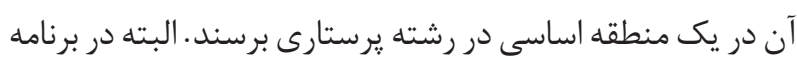


را ترجيح مى دهند بنابر اين، دانشجويان فارغ التحصيل از دكتراى

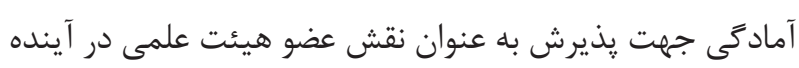

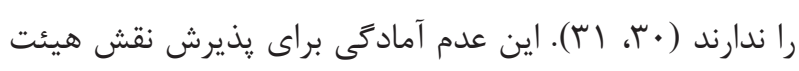

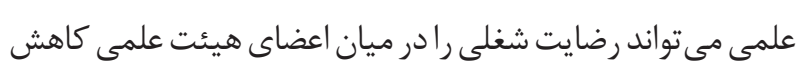

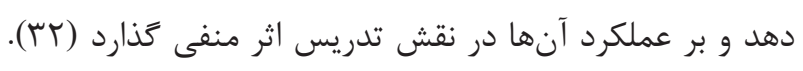

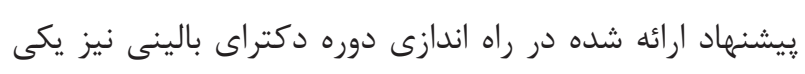

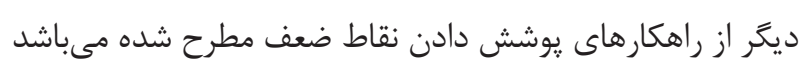
كه انتظار مىرود هر خه زودتر اجرايى كرددد.

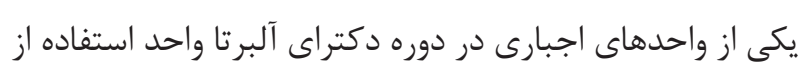

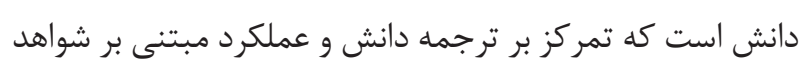

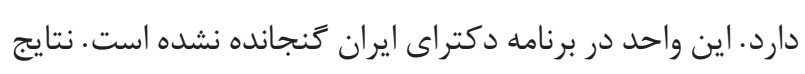
مطالعات نشان مى دهد يكى از عللى كه منجر به شكاف بين تئورى

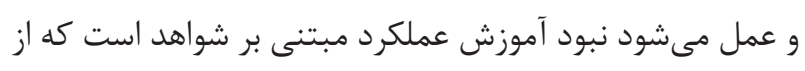

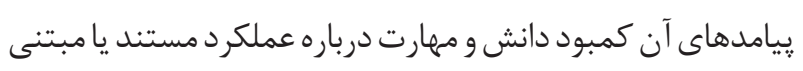

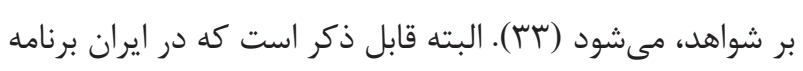

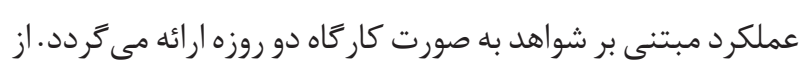
نقاط قوت برنامه دكتراى در ايران مى توان به تفكر نقادانه، استدلال

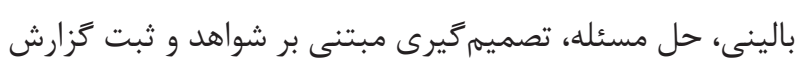

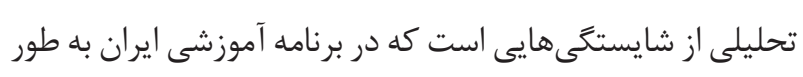

مستقيم به كسب آنها اشاره شده است (TY).

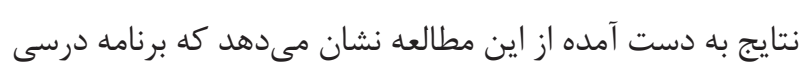

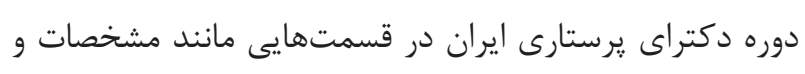

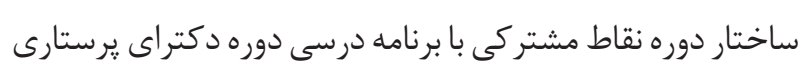

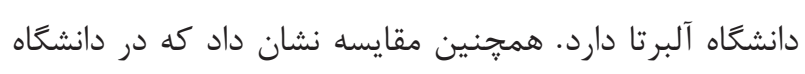

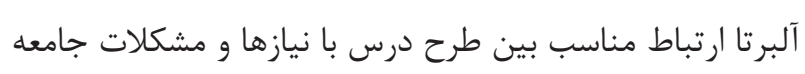
است. لذا، بايد از تجارب كشورهاى پيشرفته داراى تجربه و نظام

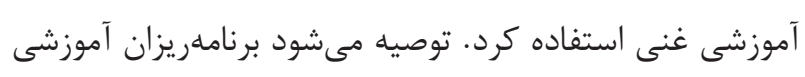

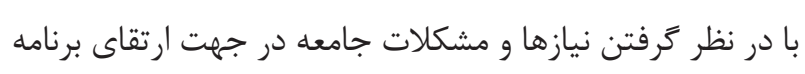

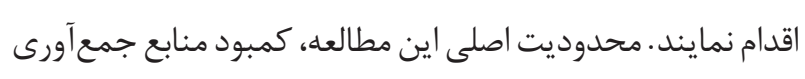
دادها در مورد دانشخاه آلبرتا بود.

\section{تضاد منافع}

بدين وسيله نويسندكان تصريح مىنمايند كه هيج گُونه تضاد منافعى در خصوص يزوهش حاضر وجود ندارد.
بالا هدف خود را سلامت جامعه جهانى قرار داده است در حالى كه در ايران اين رسالت محدود به مرزهاى جغرافيايى كشته است. كرمانشاهى و همكاران در مطالعهشان نياز به بازبينى در برنامههاى دردي دوره تكميلى را از نظر همسويى با فلسفه و رسالت و اهداف تربيت

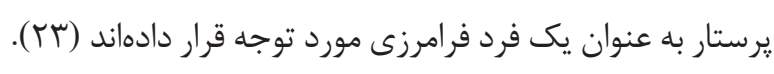

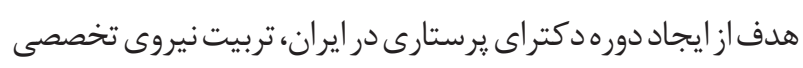

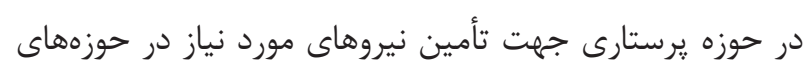

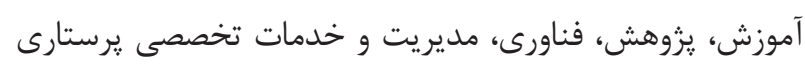
است. مطالعه منكلى كه در زمينه ارزيابى كيفيت آموزش دون دوره

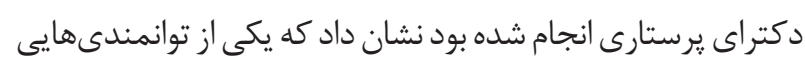

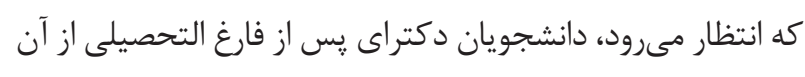

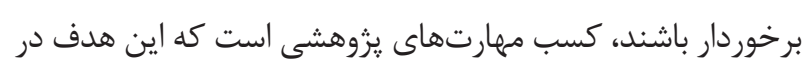

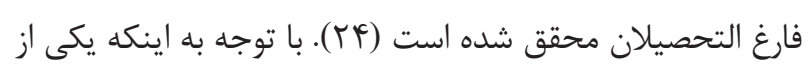
اهداف تربيت استاد و ارتقاى آموزش يرستارى است است اما در اين راستا

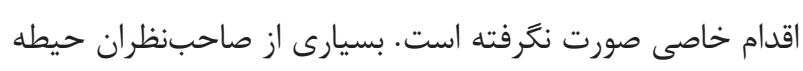
آموزش معتقدند كه تمركز فعلى دانشكدههاى يرستارى بر آماده

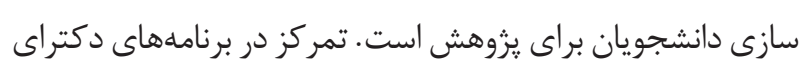

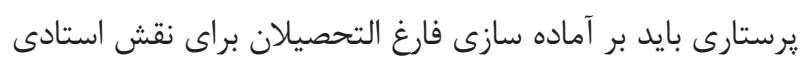
و كسب صلاحيت آموزش بالينى باشد (TO). به طورى كه نتايج

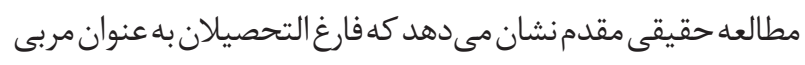

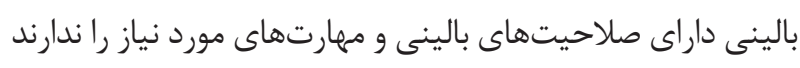
در نتيجه نمى تواند انتظارات دانشجويان و كاركنان بالينى رابر آرورده

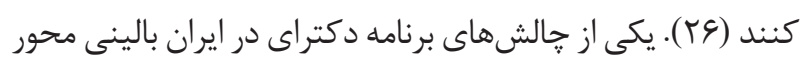
نبودن كوريكولوم دوره دكتراى و تأكيد صرف بر تئورى و خصوصاً

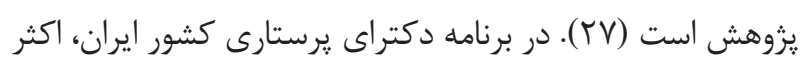

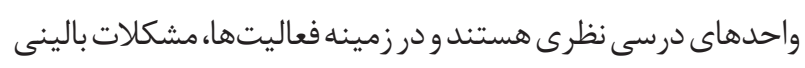

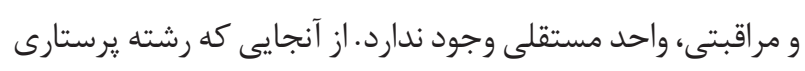
مبتنى بر علوم عملى است، بنابر اين، محققين و عالمين اين رشته

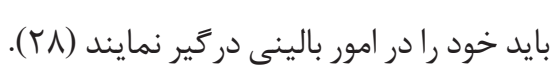

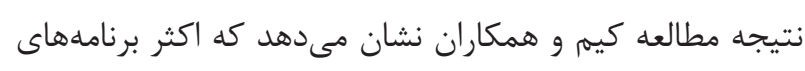

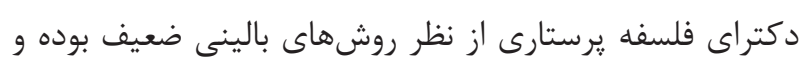
مركزيت برنامهاى آن بر روى روش هاى تحقيق است (Yq) ). مطالعات

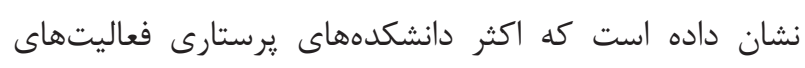

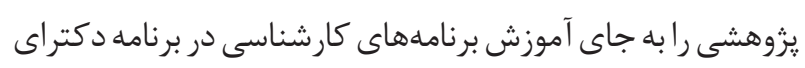




\section{References}

1- Deng F-F. Comparison of nursing education among different countries. Chinese Nurs Res. 2015;2(4):96-8.

2- Wu F-q, Wang Y-1, Wu Y, Guo M. Application of nursing core competency standard education in the training of nursing undergraduates. International J Nurs Sci. 2014;1(4):367-70.

3- Aliyari S, Maleki H, Pazargadi M, Abbaspour A. Developing and standardization of quality evaluation and accreditation indicators for curricula of baccalaureate degree nursing education in Iran. Annal of Military and Health Sci Res. 2012;10(1):50-61.

4- Naseri N, Salehi S. Accreditation of nursing education in Iran: Documenting the process. Iranian J Nurs \& Midwif Rese. 2008;12(4)

5- Jafari Asl M, Chehrzed M, Ghanbari A. Quality of educational services from viewpoint's of nursing and midwifery students of Guilan University based on Servqual model. Rese in Medical Education. 2014;6(1):50-8.

6- Robb WJ. DNSc, ND: the ABCs of nursing doctoral degrees. Dimens Crit Care Nurs. 2005;24(2):89-96. PMID: 15827432

7- Sajjadi S, Nourabadi S. Explaining and analyzing the nature and function of philosophy of education as an interdisciplinary field. Iranian J Cultural Res. 2010;2(2):19-41.

8- Rassouli M, Zagheri Tafreshi M, Esmaeil M. Challenges in clinical nursing education in Iran and strategies. Clinical Excellence. 2014;2(1):11-22.

9- McKenna H, Keeney S, Kim MJ, Park CG. Quality of doctoral nursing education in the United Kingdom: exploring the views of doctoral students and staff based on a cross-sectional questionnaire survey. J Adv Nurs. 2014;70(7):1639-52. DOI: 10.1111/jan.12326 PMID: 24308405

10- Aliyari S, Maleki H, Pazargadi M, Abbaspour A. Developing and standardization of quality evaluation and accreditation indicators for curricula of baccalaureate degree nursing education in Iran. 2012.

11- Dede S, Baskan GA. Theoretical basis of comparative education and suggestion of a model: Comparative education council in Turkish education system. Procedia-Social and Behav Scie. 2011;15:3536-42.

12- Ebrahimi S, Gangi Khezerlak A. Comparative study of information and communication technology development strategies in primary education of America, Australia and Iran. Inter J Basic Scie \& Apply Rese. 2015;4(1):1-5.

13- Alberta TUo. Faculty of Nursing 2019 Available from: https:// www.ualberta.ca/nursing.

14- Alberta TUo. University Rankings in Canada 2019 Available from: https://www.ualberta.ca/why-ualberta/university-rankingsin-canada.

15- School of Nursing and Midwifery TUoMS. General Specifications Ph.D. of Nursing 2019 Available from: http://fnm.tums.ac.ir/ userfiles/graduate/NURSING-PH.D.pdf.

16- Education EACfMM. 2019.
17- Moonaghi HK, Valizadehzare N, Khorashadizadeh F. Programs in nursing in Iran and Canada: A qualitative study. J Pak Med Assoc. 2017;67(6):863-8. PMID: 28585583

18- Rafati F, Khandan M, Sabzevari S, Nouhi E. Comparative study of nursing Ph.D. curriculum in Iran and Widener university. Iranian J Med Educat. 2015;15:555-68.

19- Roshanzadeh M, Tajabadi A, Aghaei M. The educational system and curriculum of Ph.D. nursing students in Iran and Toronto, Canada: a comparative study. J Develop Strategies in Med Educat. 2018.

20- Bereday GZ. Reflections on comparative methodology in education, 1964-1966. Comparative Education. 1967;3(3):169287.

21- Sciences. MoHpiNCbSCoPUoM. 2018.

22- Borzou SR, Oshvandi K, Cheraghi F, Moayed MS. Comparative study of nursing Ph.D. education system and curriculum in Iran and John Hopkins school of nursing. Educ Strategy Med Sci. 2016;9(3):194-205.

23- Kermanshahi S, Memarian R, Heseni A, Zamzam S, Nezamli F. A comparison post-graduate MS curriculum of nursing education in Iran and Canada. J Med Educat Develop. 2011;4(6):48-54.

24- Mangeli M, Roudi Rashtabadi O, Sabzevari S, Nouhi E. Quality Assessment of Nursing Doctoral Education from the Viewpoints of lecturers and Students/Graduates. Strides in Develop of Med EducaT. 2015;12(1):249-65.

25- Melnyk BM. Distinguishing the preparation and roles of Doctor of Philosophy and Doctor of Nursing Practice graduates: national implications for academic curricula and health care systems. J Nurs Educ. 2013;52(8):442-8. DOI: 10.3928/01484834-20130719-01 PMID: 23875724

26- Haghighi Moghadam Y, Atashzadeh-Shoorideh F, Abbaszadeh A, Feizi A. Challenges of Ph.D. Graduated Nurses for Role Acceptance as a Clinical Educator: A Qualitative Study. J Caring Sci. 2017;6(2):153-61. DOI: 10.15171/jcs.2017.015 PMID: 28680869

27- Sahebihag MH, Khaje Goudari M, Moghbeli G, Soheili A, Khadivi A, Valizadeh L. The challenges of nursing doctoral curriculum in Iran: a critical look based on Delphi technique. The J Urmia Nurs Midwifery Fac. 2017;15(6):424-39.

28- McEwen M, Bechtel GA. Characteristics of nursing doctoral programs in the United States. J Prof Nurs. 2000;16(5):282-92. DOI: 10.1053/jpnu.2000.9458 PMID: 11033938

29- Kim MJ, Park CG, McKenna H, Ketefian S, Park SH, Klopper H, et al. Quality of nursing doctoral education in seven countries: survey of faculty and students/graduates. J Adv Nurs. 2015;71(5):1098109. DOI: 10.1111/jan.12606 PMID: 25627175

30- McDermid F, Peters K, Jackson D, Daly J. Factors contributing to the shortage of nurse faculty: a review of the literature. Nurse Educ Today. 2012;32(5):565-9. DOI: 10.1016/j.nedt.2012.01.011 PMID: 22336475 
31- Deyoung S, Bliss J, Tracy JP. The nursing faculty shortage: Is there hope? J Prof Nurs. 2002;18(6):313-9. DOI: 10.1053/ jpnu.2002.129978 PMID: 12486637

32- Whitehead PS. Role ambiguity, role strain, job dissatisfaction, and difficulty transitioning into academia among nursing faculty. 2015.
33- Nehrir B, Rejeh N, Ebadi A. The evidence-based nursing education. J Nurs Edu. 2013;2(1):49-54.

34- Adib-Hajbaghery M, Hosieni F. Comparison of Expected Potentials of Ph.D. Nursing Students in Iran and Top Universities of the World. Iran J Nurs. 2018;31(113):30-41. 